\title{
Religion or Tradition: The Lack of Modernisation in the Arab World
}

\author{
by Jan-Erik Lane
}

\begin{abstract}
The recent spectacular upheavals in the Arab countries express the zest for modernisation in the Arab civilisation. It is an old quest that started when decline became undeniable in the 19th century. The call for modernisation has been temporarily retarded by authoritarian trends and Political Islam. In The Koran, there is nothing that inherently negates the demand for democracy and affluence, generated by the market economy.
\end{abstract}

Die jüngsten, aufsehenerregenden Umwälzungen in den arabischen Ländern drücken den Wunsch dieser Völker nach Modernisierung aus. Es ist dies eine alte Forderung, die seit dem Niedergang im 19. Jahrhundert zu vernehmen ist. Die Modernisierung der arabischen Welt wurde lediglich zeitweise durch autoritäre Entwicklungen und den politischen Islam verzögert. Der Koran schließt Forderungen nach Demokratie und marktwirtschaftlich erschaffenem Wohlstand nicht aus.

\section{Introduction}

The democratic revolution in several Arab countries that was initiated in late 2010 may be interpreted as a rational reaction to the process of decline that the countries face in the period of globalization. It has been especially severe for the Arab countries that lack the economic rent lifting the Gulf States out of poverty. Actually, the debate about a profound modernization deficit in the Arab world may be traced back to the 19th century, when many Arab scholars, writers and politicians stated that the Arab world must accept modernity and its institutions in order to keep up with other civilizations, especially the Europeans. ${ }^{1}$

At the same time, however, another current in Arab culture - Salafism - started to launch the fundamentalist theory that only islamisation could break the trend of decline, economically as well as politically. The idea of an Islamic society an Islamic state as well as an Islamic economy - was developed in the 20th century by groups in Pakistan (Maududi) and Egypt (Qutb, Faraj), outlining a com- 
pletely different future for Islamic countries than the path of modernisation towards a modern or post-modern society, based upon political democracy and the market economy.

Analysing the lack of modernisation in the Arab world, one may debate how to account for the comparatively low scores of several of these states on a number of indices on aspects of modernisation. First, the Arab countries will be evaluated in terms of standard indicators upon outcomes, such as democracy, rule of law and economic affluence as well as economic growth. Second, the explanatory argument of the modernisation deficit in Arabia will suggest that tradition trumps religion, when accounting for backwardness in large parts of the Arab world. The Moslem civilisation comprises some 1 billion people today, where the non-Arabs are more numerous than the Arabs. Below, only Arab countries will be identified in the Figures.

\section{Indices on the Lack of Modernisation in the Arab World}

One may employ some of the standard indices on social, political and economic development in order to tap the present situation in the Arab countries. First, we turn to the complex index on democracy, constructed by Freedom House and employed for measurement purposes over a few decades. In 1973, Freedom House launched its annual global survey of political rights and civil liberties, Freedom in the World. The Freedom House indicator on democracy is a complex one, consisting of numerous indices on the political system, such as human rights, political competition and judicial autonomy.

Figure 1 (on the following page), displaying the countries of the world according to levels of political democracy and the percentage of Muslims in the population, shows how many of the states in the Arab League perform in the early 21 st century.

The overall scores, ranging from 10 to 0 , summing up a variety of aspects of democracy, are low for the Arab countries. One may point out that Egypt displays a somewhat better score than Tunisia, but both countries are solidly placed in the set of dictatorships, lower than for instance Bahrain, Lebanon, Kuwait and the Comoros.

Second, one may employ the data from the Governance project by the World Bank. Out of the six composite indices that the project constructed and employed in a global mapping of some 200 countries around 2000, two are particularly relevant for democracy assessment. On the one hand, there is the integrity of the 
legal system and the autonomy of the courts, measured by the aggregation of a host of indices, such as the transparency index, the economic institution indices, and parts of the human rights index such as habeas corpus.

Figure 1: Democracy in the Arab World (Freedom House Index 2008)

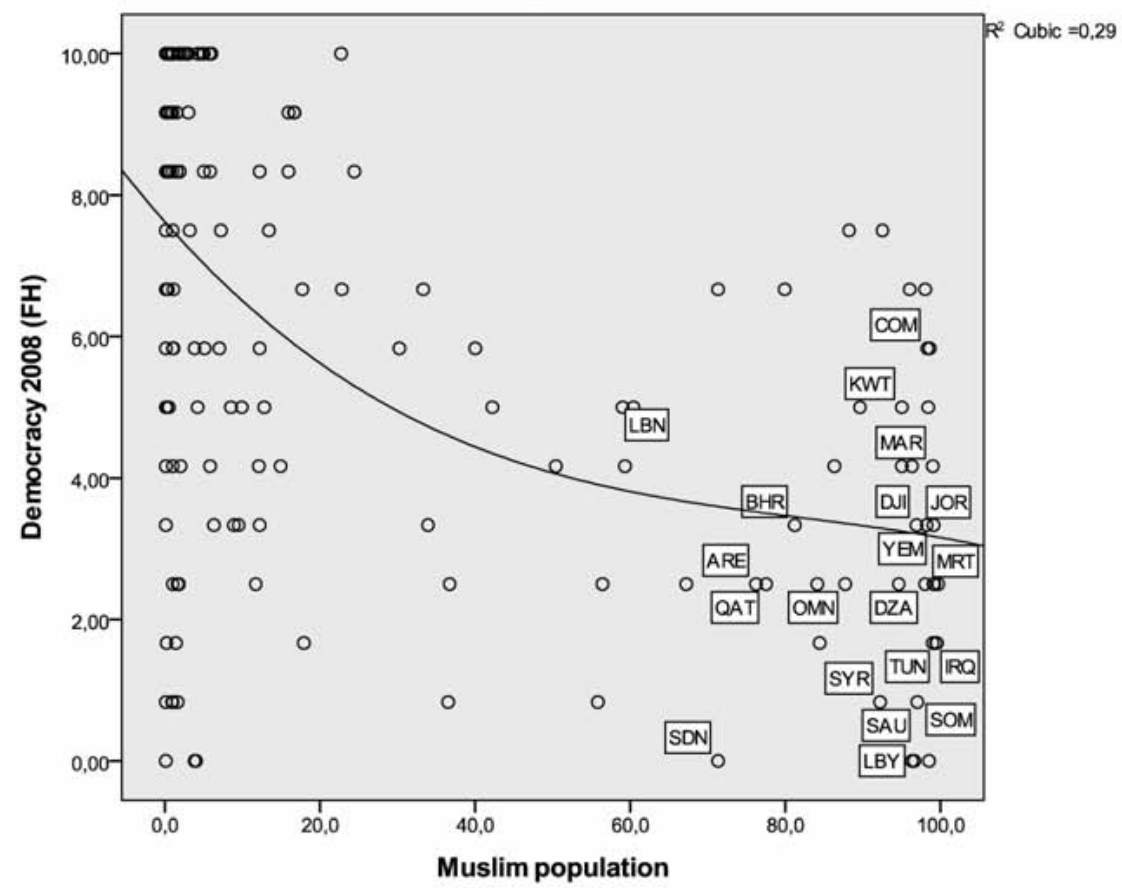

Sources: Democracy 2008 - Freedom House: Freedom in the World, New York, NY, 2010, data available at: http://www.freedomhouse.org/template.cfm?page=439. Muslim population - Pew Forum: Mapping the Global Muslim Population: A Report on the Size and Distribution of the World's Muslim Population, October 2009, Washington, D.C., data available at: http://pewforum. org/Mapping-the-Global-Muslim-Population.aspx.

On the other hand, the Governance project measured voice and accountability in the political process of a country, which will be called rule of law II here. ${ }^{2}$

The Rule of Law I index taps how the court system operates in various countries, from the standpoint of the ideal of a Rechtsstaat. Figure 2 displays the scores for the Arab countries.

2 Lane, J.-E.: Constitutions and Political Theory, Manchester, 2011. 
Figure 2: Rule of Law I (due legal process) in the Arab World

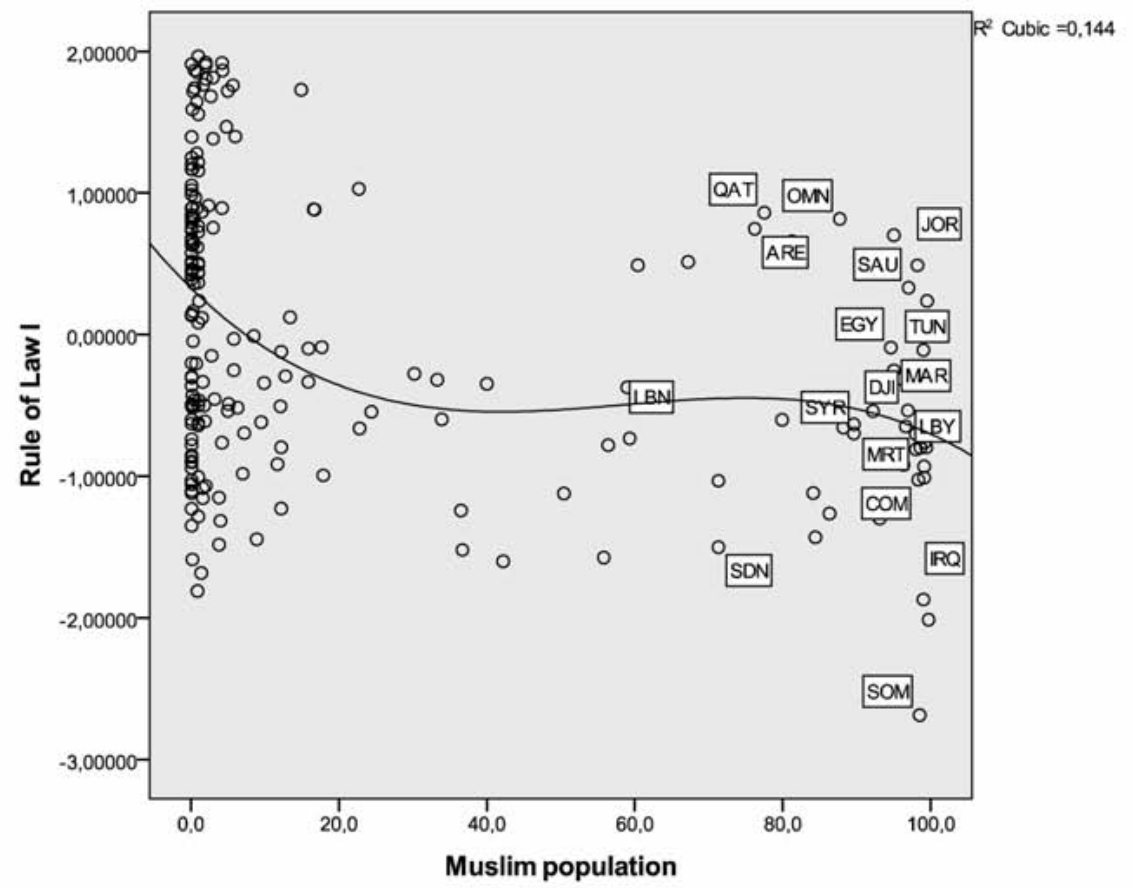

Source: Estimates of Rule of Law I as judicial autonomy - World Bank: The Worldwide Governance Indicators (WGI) Project, Washington, DC, 2010, data available at: http://info.worldbank.org/ governance/wgi/index.asp.

According to the estimates of legal integrity and judicial autonomy, the court system in most Arab countries does not perform well. The only exception is the set of superrich Gulf States, but these scorings may involve an overestimation. Egypt and Tunisia score close to 0 on the scale ranging from +2 to -2 .

On the other hand, the Governance project also uses the index upon voice and political accountability. It may be employed as an indicator for political competition as well as free and fair elections, meaning the unrestrained representation of the people and the derivation of law from the consent of Parliament or the National Assembly. Figure 3 shows how Arab countries perform on political legitimacy derived from voice and accountability (Rule of Law II). 
Figure 3: Rule of Law II: Voice and accountability in the Arab World

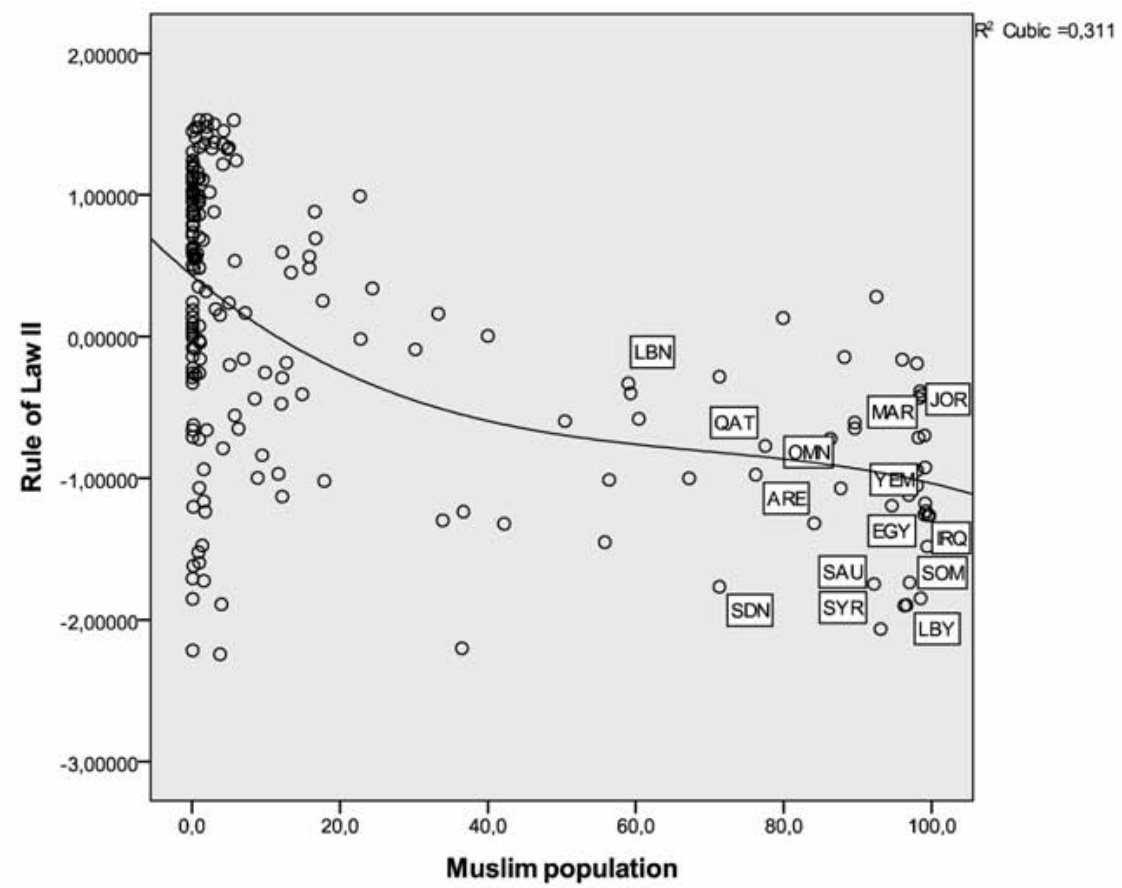

Source: Estimates of Rule of Law II as voice and accountability - World Bank: The Worldwide Governance Indicators (WGI) Project, Washington DC, 2010, data available at: http://info. worldbank.org/governance/wgi/index.asp.

The comparative measures on voice and accountability put the Arab countries very low, such as, for instance Egypt, the United Arab Emirates, Yemen and Tunisia. Globally speaking, one notes the profound lack of the various aspects of rule of law in the Arab World, both rule of law as judicial autonomy as well as rule of law as representative government.

It must be a burden for the population in these countries not to be able to expect legal predictability and not to be able to express their preferences for their representatives in free and fair election. One may wish to add the general economic situation in the Arab world to the performance evaluation of these countries. 
It should be pointed out that the Gulf States and Libya enjoy a so-called rentier economy. ${ }^{3}$ This means that they derive almost all of the GDP from the export of oil and gas, involving a huge economic rent. Algeria and Iraq benefit from a similar rent, although not at all to the same extent. Figure 4 shows the gross national income per capita in Arab countries.

Figure 4: Gross National Income per capita in the Arab countries

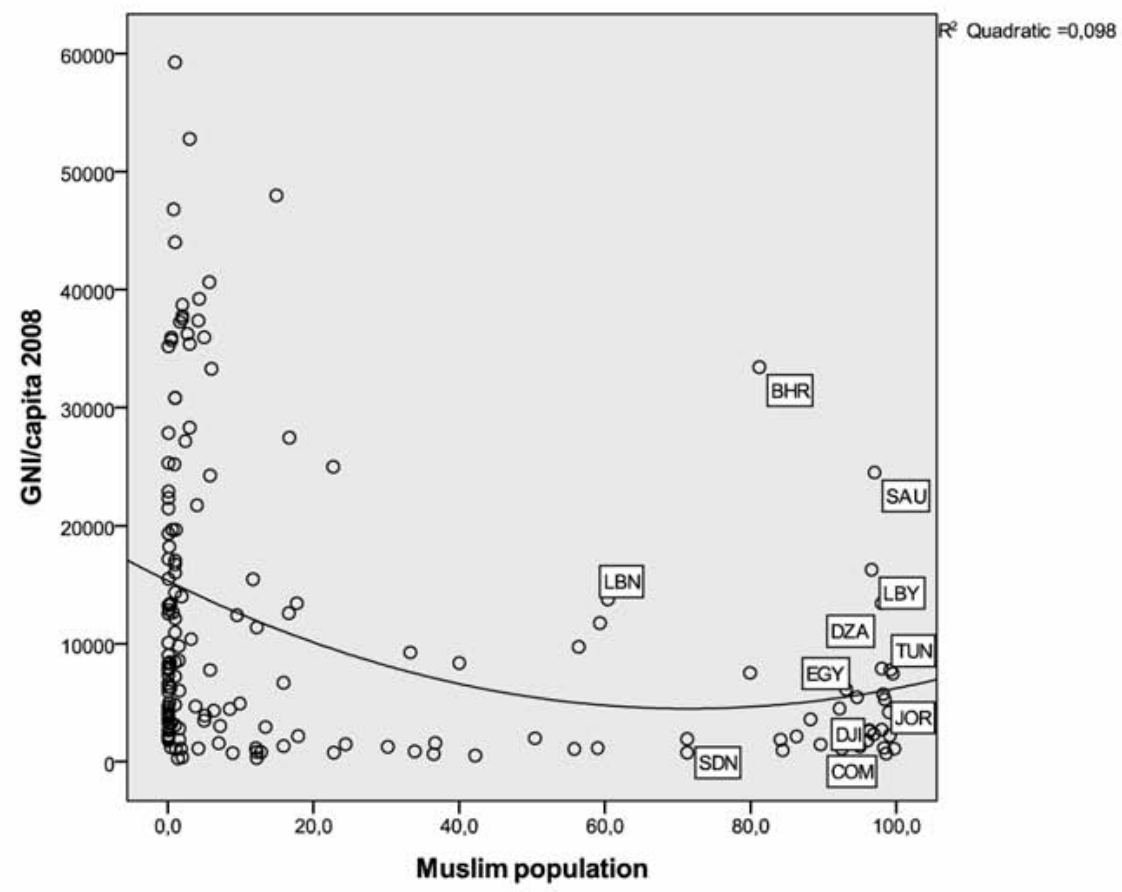

Source: GNI per capita - World Bank: World Development Indicators, Washington D.C., 2010, data available at: http://databank.worldbank.org/ddp/home.do.

Excluding the rentier economies, the average person in the Arab world disposes of a low income, in Egypt lower than in Tunisia. Bahrain has used up its oil and thus scores below the superrich Gulf States: UAE $(43,300)$, Qatar $(113,000)$ and Kuwait $(56,400)$, the latter numbers being somewhat uncertain though.

Actually, the rates of economic growth in many Arab countries are not high enough for the economy to provide jobs for the large numbers of young people

3 Beblawi, H.: The Rentier State in the Arab World, in: Luciano, G.: (ed.): The Arab State, Berkeley, 1990, 85-98. 
that high population growth throws up. This is conducive to the profound problem of distribution of resources and social justice, which poses a most important element within the Jasmine upheavals.

Figure 5 displays the average economic growth rates for Arab countries during the last decade.

Figure 5: Economic growth rates in Arab countries

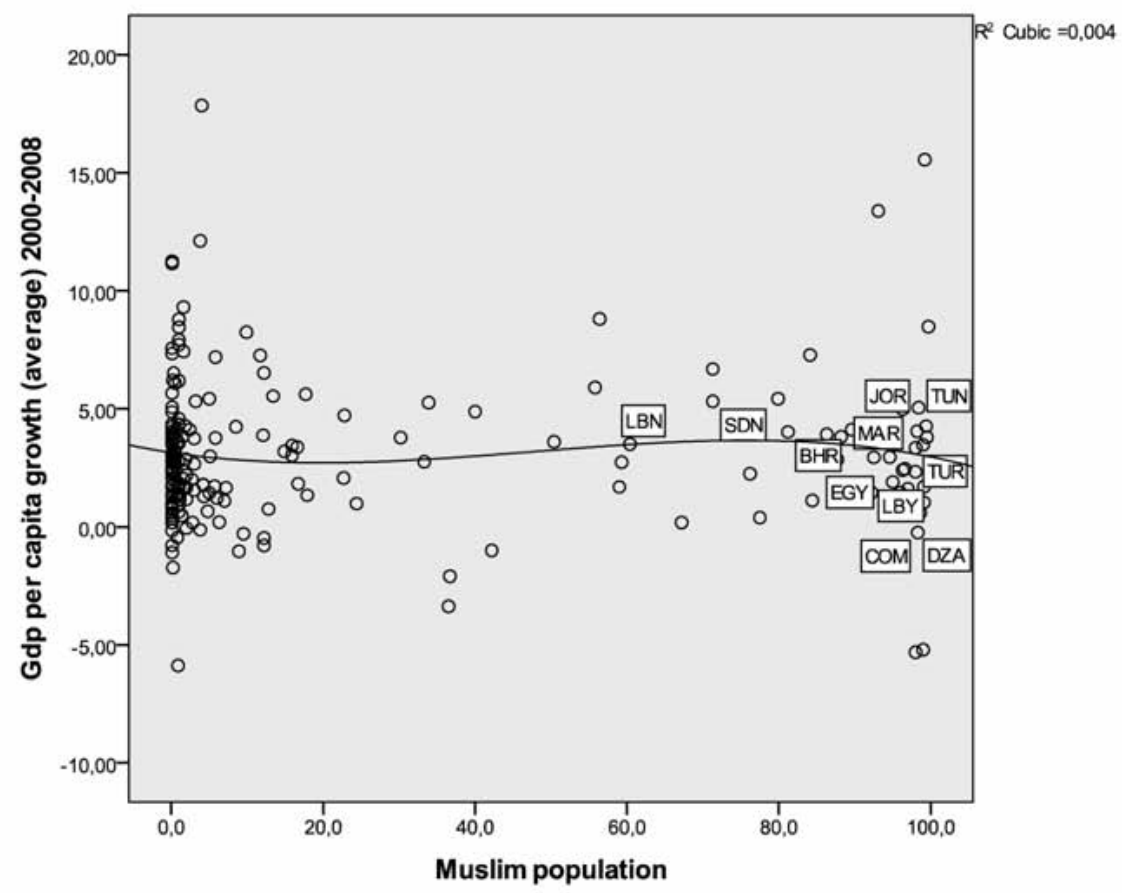

Source: GDP per capita growth 2000-2008 - World Bank: World Development Indicators, Washington D.C., 2010, data available at: http://databank.worldbank.org/ddp/home.do.

Although economic growth has been positive in most Arab countries over the last ten years, their economies are hardly dynamic enough to create economic prospects for the many young people in the economy, especially as the income distribution is skewed. The current growth rates for the Maghreb countries Algeria, Morocco and Tunisia - and Egypt are actually rather mediocre.

To sum up: It is the combination of lack of human rights in a broad sense and weak economic development that creates the strong sources for social and political unrest in the Arab world. The process of globalisation makes it easy for the 
population to compare their situation with that in other civilisations. Figure 6 shows that the Arab countries are rather integrated in the global economy or the global village.

Figure 6: The Arab countries according to the Globalisation index

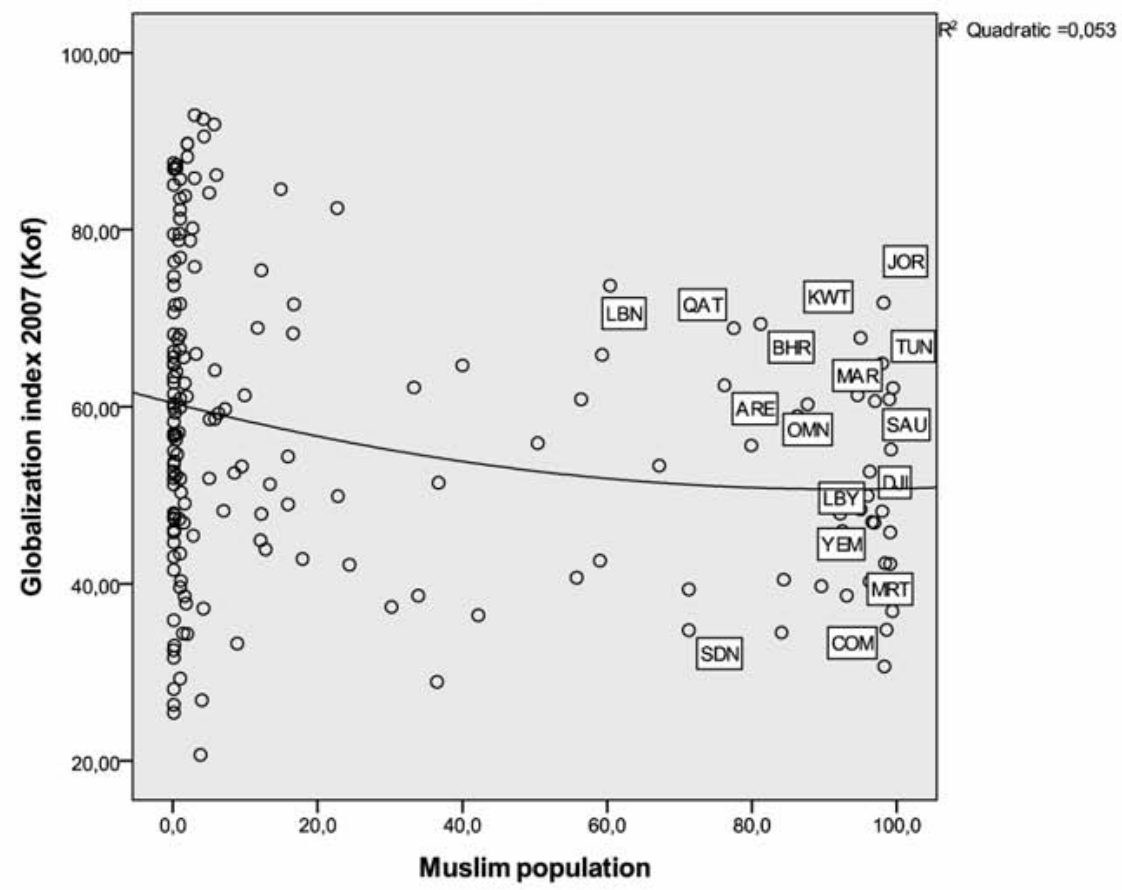

Source: KOF Globalization index - Dreher, A.: Does Globalization Affect Growth? Evidence from a new Index of Globalization, in: Applied Economics 38/10 (2006), 1091-1110, data available at: http://globalization.kof.ethz.ch.

When the Arab countries with the exception of the Gulf rentier economies enjoy neither political freedom nor economic prosperity, then political authoritarianism cannot be maintained indefinitely. In addition, the anger of ordinary people about their plight is increased by the rumours of excessive enrichment in the entourage of the top political elite.

\section{A Few Explanations or Theories of Arab Backwardness}

The analysis of the backwardness of Arab countries, combining an authoritarian regime with weak economic development, may focus upon a few factors shedding light on the Arab situation today. As I wish to argue that tradition is far 
more important than religion for the average Arab outcomes in the performance assessment above, traditional features will be underlined at the expense of Islam below. Let us start with politics.

\section{No Political Rationalisation: Tradition and Charisma}

Speaking generally, there exist only three kinds of political authority, as Weber elaborated in the Herrschaftssoziologie, namely: legal-rational, charismatic and traditional authority. Weber regarded the bureaucracy as the hallmark upon the modern state with its legal-rational authority, ${ }^{4}$ but an alternative interpretation would link the legal-rational type of political authority with constitutionalism and rule of law.

The Arab countries are governed by either traditional authority or charismatic authority, almost with no exception. ${ }^{5}$ Why is that so? When traditional rule is crushed by means of charisma or a military coup, then it is replaced in Arabia by charismatic authoritarianism, tending often to create a new dynasty. Never is the constitutional document respected. Instead constitutions are made and unmade, changed or suspended. At the end of the day, authoritarianism remains in place, also in countries where traditional authority survives, as in real monarchies within the region. ${ }^{6}$

\section{Law and the legal order}

The lack of constitutionalism in the sense of government under the laws, restraining the exercise of power, is acerbated by the strong position of revealed law - Sharia - in the legal systems of Arab countries. Some of these countries have developed rational systems of law - civil law or common law - but Islamic law has made strong inroads lately.

One often raised objection against Islamic Law is that it is very old-fashioned, laid down in the 9th and 10th centuries in the form of four schools of jurisprudence - the so-called figh. Although it is always stated that the gate of interpretation has been closed for ever, Islamic law has developed in various ways, using different kinds of methods, even tricks, to update the legal order so that law can adapt to the changes in society.

4 Weber, M.: Economy and Society, Berkeley, 1978, 212-301.

5 Elbadawi, I./Makdisi, S. (eds.): Democracy in the Arab World: Explaining the Deficit, London, 2010.

6 Billingsley, A.: Political Succession in the Arab World, London 2009; Lacey, R.: Inside the Kingdom: Kings, Clerics, Modernists, Terrorists, and the Struggle for Saudi Arabia, London, 2010. 
Yet, this way of adapting law to the social evolution comes with a price, namely a fundamental arbitrariness typical of Qadi-justiz, as Weber called Islamic Law. ${ }^{7}$ There is simply too much discretion when the Islamic court applies old rules, making it difficult to predict the outcome for ordinary people. The result is a fundamental feeling of uncertainty concerning legal matters, whether public or private law ones.

\section{Family system}

One may make a sharp distinction between two types of family systems: individualistic and collectivistic ones, following the concepts introduced by $T o d d^{8}$. In the ideal-type of an individualistic family system, the children leave the family house at the age of 18 to 21 , developing into legal subjects on their own, managing their own lives. The parents cannot count on being cared for at old age. It has been argued that such an individualistic family promotes democracy in general. However, the family system in the Arab countries tends to be of the collectivistic kind. It is a drag upon gender equality as well as civil society. ${ }^{9}$ The scores for gender empowerment are low in the Arab countries - see Figure 7. It is obvious from this figure that the overall predicament of Muslim women is certainly not an easy one. The economic institutions are also run with a collectivist bend.

7 Weber, M., op. cit., 809-838.

8 Todd, E.: L'enfance du monde. Structures familiales et développement, Paris, 1984.

9 Cavatorta, F./Durac, V.: Civil Society and Democratization in the Arab World, London, 2010. 
Figure 7: Gender empowerment in the Arab countries

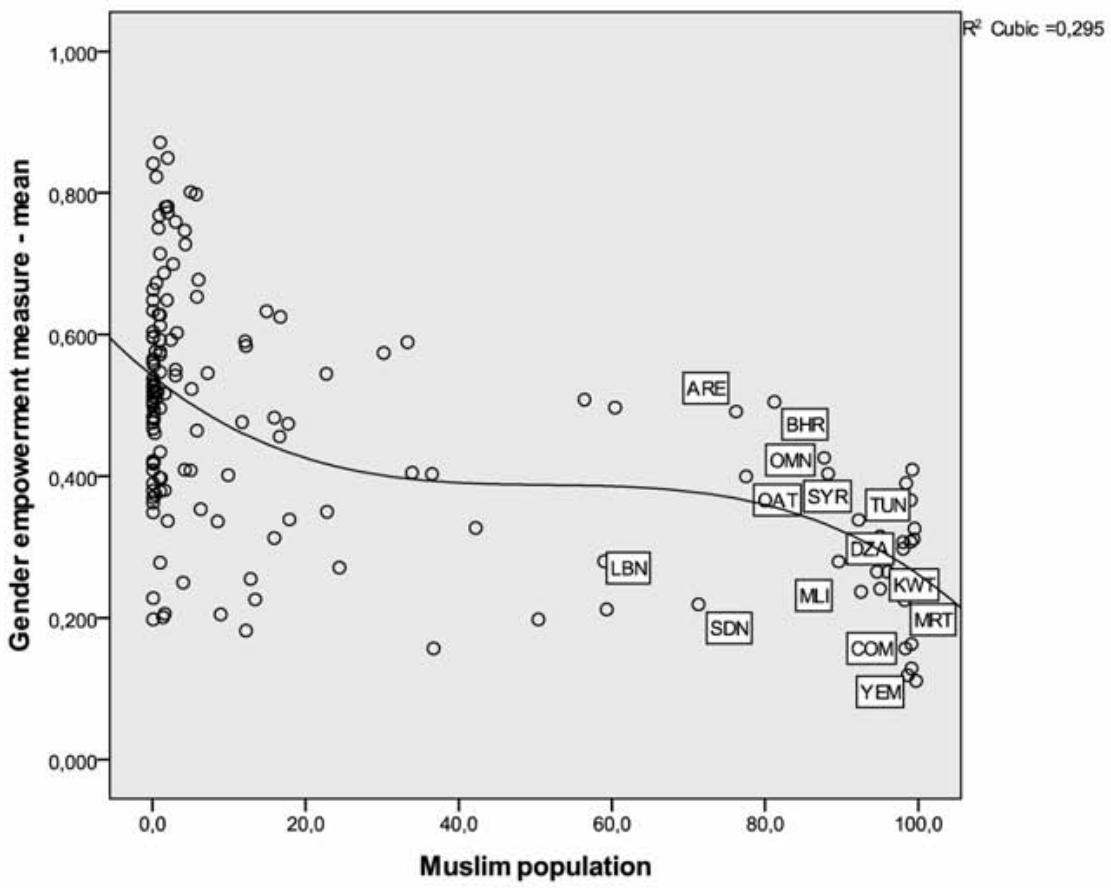

Source: Gender Empowerment Measure (mean values) - UNDP: HDR 2010 Statistical Tables, New York, 2010, data available at: http://hdr.undp.org/en/statistics/data.

\section{Economic institutions}

The Arab countries have never fully endorsed the market economy with its competitive individualism. Instead, they all practice state-capitalism, meaning that government regulates the economy in detail and the state is often a large owner of land, factories and banks. ${ }^{10}$ The outcome is an economy focusing upon the favours that the President and his entourage can provide when accepting permits or applying regulations. State-capitalism tends to degenerate into various forms, simple or elegant ones, of looting and corruption. What has thus far come out about the fortunes amassed by the Tunisian Ben Ali and the Egyptian Mubarak family indicates, even if numbers are exaggerated, that mass poverty in these countries is not the only aspect of their distribution of income and wealth. Espe-

10 Luciani, G.: Allocation vs. Production States: A Theoretical Framework, in: id. (ed.): The Arab State, Berkeley, 1990, 65-84. 
cially in Egypt, a middle class is lacking. Economic growth cannot, however, be driven only by conspicuous consumption by a small super rich top strata - a clique. Figure 8 displays the extent of economic freedom, according to one of the standard indices upon the enforcement of market institutions.

Figure 8: Economic freedom in the Arab world

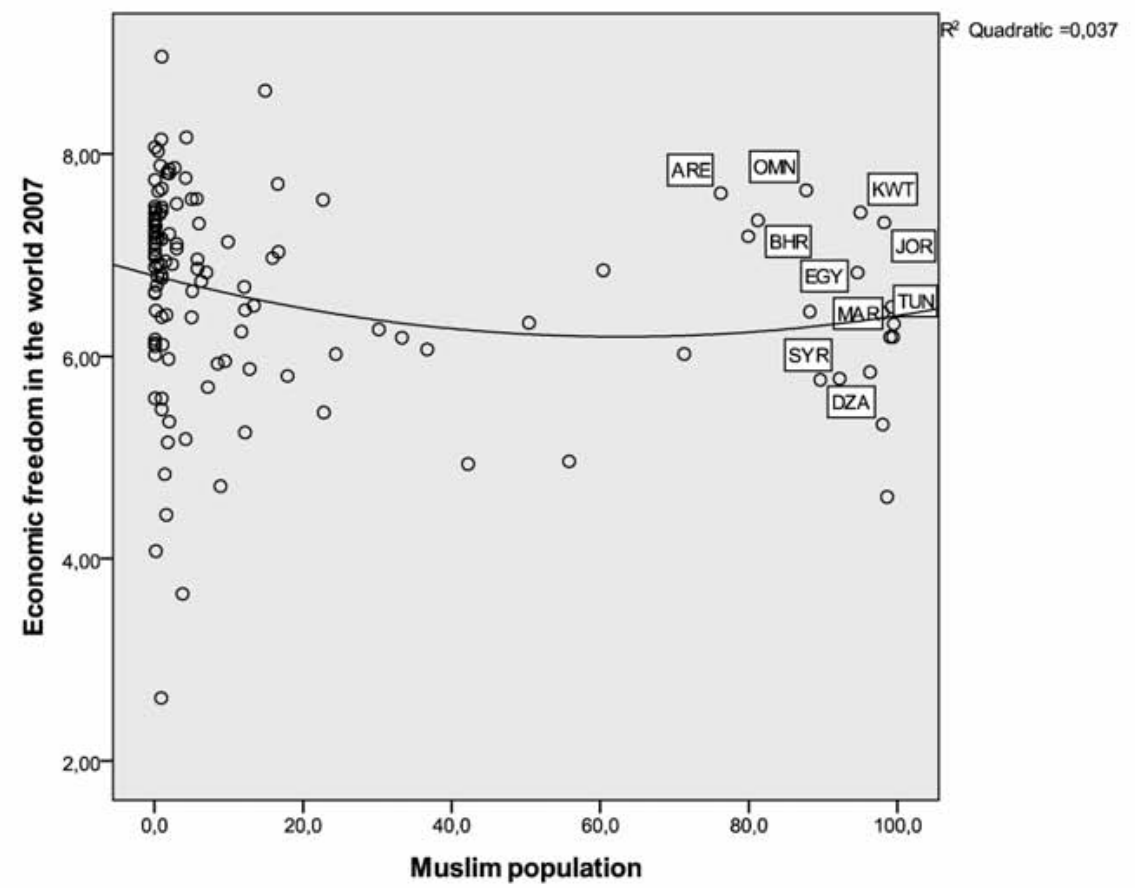

Source: Economic Freedom of the World - Gwartney, J.D./Hall, J.C./Lawson R.: Economic Freedom of the World, 2010 Annual Report, Vancouver, BC, 2010, data available at: http://www.freetheworld. com/datasets_efw.html.

The extent of economic freedom - the scope for the institutions of lawful capitalism - is narrow in Arab countries, with the exception of the rentier economies. However, only the market economy can deliver the jobs necessary to accommodate the immense demand among youngsters in Arabia - see Figure 9. 
Figure 9: The relative size of young people in Arab populations

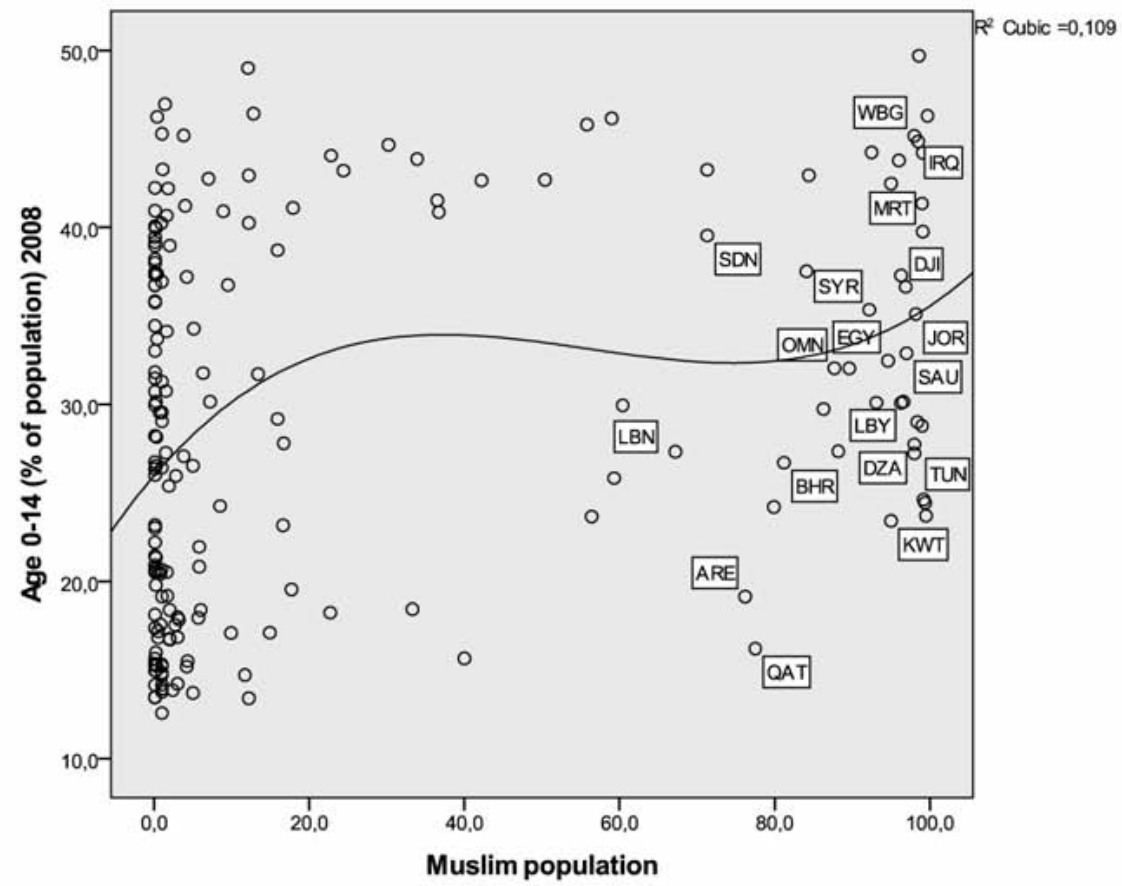

Source: Per cent of population age 0-14 - World Bank: World Development Indicators, Washington D.C., 2010, data available at: http://databank.worldbank.org/ddp/home.do.

It is the poor Arab countries that have the largest youth cohorts, relatively speaking. This puts enormous pressure upon both the economy and the educational system in these countries. However, it is well-known that mass education has lagged behind for many years in Arabia.

\section{Colonisation - Heritage of Violence}

Against the explanations above, focusing upon Arab traditionalism and other internal factors, one can argue that these explanations bypass a most fundamental experience that most Arab countries share, although with somewhat different memories, namely European colonialism. What seem to have stalled the development of Arab countries are the external domination and the attending fight against it, resulting in legitimising the use of physical violence and other forms of repression. ${ }^{11}$ 
There are various versions of this dependency approach, or orientalism, as it is called with regard to the Arab countries. Whether Weber could be designated as an orientalist, considering his scepticism about Arab traditions and perhaps also with regard to the religion of Mohammed, has not been debated in the literature. Said $^{12}$ in his investigations into orientalism, culture and colonialism made no reference whatsoever to the writings of Weber on Islam and Arabia, scattered through his major books, despite the negative view of Weber on some aspects of Arab politics and law.

\section{Religion: Fitna}

Adducing that Islam has contributed to Arab backwardness would be entirely unwarranted, because religious practice is not strongly related to religion as a set of doctrines. After all, religion is what men and women make of it. What counts are the interpretations of the so-called Holy Book as well as the formation of social practice under the influence of tradition, for instance in the figh (jurisprudence). As with other world religions, there have been different interpretations of The Koran along the history of Islam, resulting in much controversy ${ }^{13}$ as well as divisions.

The interpretation of the Koran launched by the fundamentalists is based upon an approach to Arab decline that seeks the solution in going backwards, the Arabia of the four Righteous Caliphs (Salafism). 20th century radical fundamentalism in Pakistan and Egypt has added the ominous notion of jihad - the hidden duty (Faraj). ${ }^{14}$ Political Islam entails total islamisation of state and society, according to the ideas of Maududi and $Q u t b^{15}$. It will not bring modernization - democracy and affluence - to the Arab world, not even peace and social stability. ${ }^{16}$

\section{Conclusion}

Stable democracy in the Arab world seems only possible when two conditions are met. Firstly, there must be a substantial number of democrats, i.e. people who truly adhere to the democratic regime. Second, constitutionalist rules must meet

12 Said, E.: Orientalism. London, 2003; id.: Culture and Imperialism, London, 2007.

13 Kepel, G.: Fitna. Guerre au coeur de l'islam, Paris, 2004; Mervin, S.: Histoire de l'Islam. Fondements et doctrines, Paris, 2010.

14 Murawiec, L.: The Mind of Jihad, Cambridge, 2008.

15 Roy, O.: Holy Ignorance: When Religion and Culture Part Ways, London, 2010.

16 Feldman, N.: After Jihad: America and the Struggle for Islamic Democracy, New York, 2003. 
with respect and enforcement, not only as a matter of tactics but also as a concern for legitimacy. The first condition refers to the preferences of the players and groups being active today in Arab politics. The second condition is an institutionalist one, focusing upon the rules of the political game that are laid down not merely in constitutional formalia but also in constitutional realia.

Authoritarianism in the Arab world is motivated by the fear of religious fundamentalism. The one supports the other, but the outcome is the same, namely no modernization. Arab countries can only undo the horns of this dilemma when considerable groups of people start adhering to democratic rule, unhindered by religion. ${ }^{17}$ For the first time after independence, large masses of people in Arab countries display democratic preferences ${ }^{18}$ calling for the institutions of the rule of law regime as well as economic reforms that make it possible for small people to prosper. The future of the Jasmine Revolution will depend upon whether the zest for democracy and affluence can be translated into a set of firm institutions for a rule of law regime and a decentralized market economy.

17 Rutherford, B.K.: Egypt after Mubarak: Liberalism, Islam, and Democracy in the Arab World, Princeton, 2008.

18 Baaklini, A.I./Denoeux, G./Springborg, R.: Legislative Politics in the Arab World. The Resurgence of Democratic Institutions, Boulder, CO, 1999. 